\title{
PEMBUATAN KERAJINAN BERBASIS SAMPAH SEBAGAI IMPLEMENTASI PENGENDALIAN SAMPAH 3R (REDUCE, REUSE DAN RECYCLE)
}

\section{GARBAGE-BASED HANDICRAFT AS A 3R (REDUCE, REUSE, RECYCLE) WASTE MANAGEMENT IMPLEMENTATION}

\author{
Oleh: \\ Deni Agus Triawan, Nesbah, Dwita Oktiarni, Dyah Fitriani \\ Jurusan Kimia, Fakultas MIPA, Universitas Bengkulu \\ Email: deni.agustriawan@unib.ac.id
}

\begin{abstract}
Community service activities are conducted by education and training. The ultimate goal is to provide students with an understanding of $3 R$ (reduce, reuse and recycle) waste management by training students about the various crafts that can be made with wastebased. The results of the activities show a satisfactory response in which participants have high enthusiasm in improving knowledge and skills based on (reduce, reuse and recycle) waste management. The resulting products are decorative lamps of used plastic waste bottles. Hierarchy of waste management are reduce waste product, reuse waste product, recycle waste product and disposal area as a last alternative. It is expected that the participants will apply the principle of waste management with $3 R$ method in their daily life.
\end{abstract}

Keywords: waste, reduce, reuse, recycle

\section{PENDAHULUAN}

Menurut Sarnubi (Kepala Dinas Kebersihan Kota Bengkulu), sampah organik dan anorganik yang masuk ke TPA Air Sebakul sebanyak 260-280 ton. Sampah ini diperoleh dari masyarakat Kota Bengkulu. Untuk menampung sampah tersebut, lokasi TPA Air Sebakul sempat overload saat luasnya masih 3,5 hektar dan perlu dilakukan perluasan areal TPA untuk menampung sampah tersebut. Manusia menjadi penyumbang terbesar dalam peningkatan volume sampah di lingkungan. Hampir seluruh aktivitas dan kegiatan manusia menimbulkan sampah. Sampah-sampah yang dimaksud dapat digolongkan menjadi 3 (tiga) jenis yaitu sampah rumah tangga, sampah sejenis rumah tangga dan sampah spesifik (Alex, 2000). Laju pertumbuhan ekonomi dan pertumbuhan penduduk menjadikan faktor utama peningkatan jumlah sampah. Sebaliknya pertambahan jumlah sampah ini tidak diimbangi dengan pengelolaan yang ramah lingkungan sehingga akan menjadi inisiator bagi percepatan kerusakan lingkungan.

Dalam skala nasional, pemerintah memberikan pedoman dalam pengelolaan sampah melalui Peraturan Menteri Negara Lingkungan Hidup Nomor 13 Tahun 2012 Tentang Pedoman Pelaksanaan Reduce, Reuse dan Recycle melalui bank sampah. 
OPSI PALING BAIK

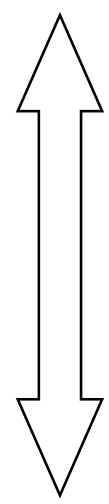

OPSI PALING BURUK

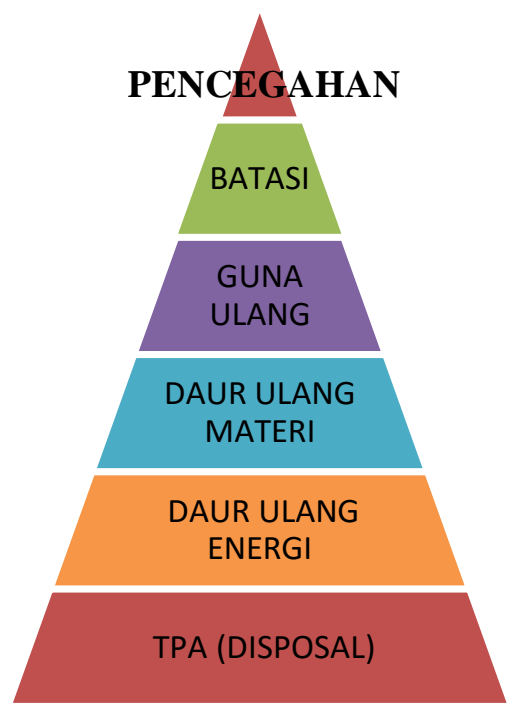

Gambar 1. Hirarki Pengelolaan Sampah Berbasis 3R (Tchobanoglous, 1990)

Di tingkat Provinsi Bengkulu, penanganan terhadap sampah telah diatur dalam Perda No 02 Tahun 2011 tentang Pengelolaan Sampah di Kota Bengkulu yang salah satunya berisi denda sebesar 5 juta rupiah atau kurungan 3 bulan apabila membuang sampah sembarangan. Tetapi hal tersebut belum cukup dapat mengendalikan sampah di Kota Bengkulu. Menurut Apryanti dan Dirgahayani (2012) partisipasi dari berbagai pihak merupakan salah satu kunci keberhasilan suatu kegiatan ataupun program. Dengan demikian partisipasi masyarakat merupakan salah satu kunci keberhasilan kebijakan dan program pengelolaan sampah dapat terselenggara secara efektif. Partisipasi masyarakat sendiri dipengaruhi oleh berbagai faktor, salah satunya adalah persepsi masyarakat terhadap suatu kegiatan. Persepsi sendiri merupakan proses penginderaan dan penafsiran rangsangan suatu objek atau peristiwa yang diinformasikan sehingga seseorang dapat menentukan tindaknnya. Di samping itu, tinggi rendahnya partisipasi masyarakat dipengaruhi oleh proses psikologis yang dialami oleh setiap individu yaitu persepsi, sedangkan positif atau negatifnya persepsi seseorang terhadap suatu hal dipengaruhi faktor dalam diri individu maupun faktor diluar individu.

Dalam hal pengendalian permasalahan tersebut, dapat dilakukan kegiatan berupa pembekalan sejak dini pada generasi muda yang peduli terhadap sampah (Amri dan Widiyantoro, 2016). Pembekalan tersebut dapat berupa pemberian informasi dan pengetahuan tentang pengelolaan sampah. Pengetahuan ini meliputi pengenalan sistem pengendalian sampah dengan sistem reduce (batasi), reuse (gunakan ulang) dan recycle (daur ulang). Sehingga generasi muda memiliki kesadaran dan kepedulian lingkungan akibat sampah. Pembekalan ini juga akan lebih baik dengan penerapan aplikasi dari sistem pengolahan tersebut yang dalam hal ini berupa pelatihan pembuatan kerajian yang berbasis sampah plastik seperti pembuatan lampu hias dari sampah botol plastik sehingga dapat bernilai guna lebih di dalam kehidupan masyarakat nantinya (Putra dan Yuriandala, 2010).

\section{METODE PENGABDIAN}

Kegiatan pengabdian diawali dengan penyampaian informasi, diskusi dan tanya jawab dengan tujuan meningkatkan pemahaman masyarakat terutama siswa TPQ tentang pengelolaan sampah dengan metode 3R (Reduce, Reuse dan Recycle). Kegiatan ini dimulai 
dengan pemaparan dan penyampaian informasi tentang sampah, jenis sampah dan pengelolaan sampah dilanjutkan dengan diskusi yang melibatkan pemahaman peserta. Setelah peserta mamahami teori tentang sampah dan pengelolaan sampah, dilanjutkan pelatihan dengan aplikasi pembuatan kerajinan berbasis sampah plastic (Syarofah, 2013).

\section{HASIL DAN PEMBAHASAN}

PPM adalah penyampaian gagasan pelaksanaan pengabdian kepada Kepala TPQ Fatimatuzzahra Kota Bengkulu berjalan lancar. Pihak sekolah siap dan bersedia menerima kedatangan tim pengabdian dari Universitas Bengkulu. Kesediaan pihak sekolah ditunjukkan dengan adanya Surat Pernyataan Kesediaan Kerjasama dari Mitra yang didapat pada tanggal 15 Maret 2016. Kesediaan kerjasama yang dimaksud adalah berupa penyediaan tempat dan fasilitas untuk terlaksananya kegiatan pengabdian serta bersedia menyebarluaskan hasil kegiatan pada komponen sekolah lainnya.

Program pengabdian berupa pelatihan pengelolaan sampah anorganik menjadi aneka kreasi daur ulang perlu terus diupayakan mengingat produksi sampah rumah tangga semakin banyak dan didukung rendahnya kesadaran 3R, yaitu reuse (memakai kembali barang bekas yang masih bisa dipakai), reduce (berusaha mengurangi sampah), dan recycle (mendaur ulang sampah agar dapat dimanfaatkan) (Dirgantar, 2013). Berdasarkan hirarki pengelolaan sampah berdasarkan 3R, opsi yang paling baik adalah mengurangi penggunaan barang/produk yang dapat menghasilkan sampah, sedangkan opsi yang paling buruk adalah membuang sampah pada tempat pembuangan akhir (TPA). Dengan melimpahnya sampah maka akan semakin banyak memerlukan TPA dan menyebabkan berbagai gangguan terhadap lingkungan dan kesehatan. Hal ini menjadi pertimbangan tim pengabdian untuk mencari cara untuk menanamkan pola fikir kepedulian terhadap sampah pada masyarakat terutama tentang prinsip 3R. Tidak hanya itu, bahkan kegiatan pengabdian juga dapat memberikan keterampilan yang dapat berhasil guna dan memiliki nilai ekonomis seperti pembuatan lampu hias.

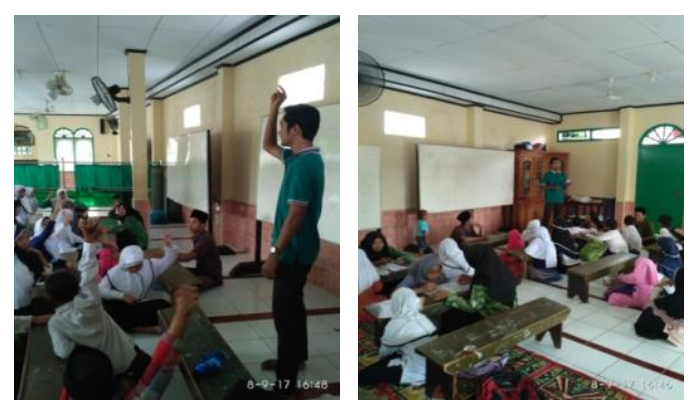

Gambar 3. Penyampaian Materi tentang Pengelolaan Sampah dengan Metode 3R

Pada tahap awal program pengabdian, peserta pelatihan diberikan pengetahuan tentang sampah, jenis sampah, dan sumber sampah, pengelolaan sampah dan 3R (reduce, reuse, recycle), serta pengelolaan sampah anorganik menjadi aneka kreasi daur ulang. Dalam tahap ini peserta pelatihan diubah pola pikirnya terhadap sampah, "jika dulunya barang bekas langsung kita buang dan menjadi tumpukan sampah", maka pola pikir ini harus kita ubah menjadi "sampah dapat kita olah menjadi sesuatu benda yang berguna" (Marlianti, 2014). Dengan menerapkan prinsip recycle, barang-barang bekas atau sampah dapat diolah kembali menjadi suatu bentuk yang memiliki daya guna seiring dengan 
kreatifitas yang dimiliki. Dengan kreatifitas yang dimiliki, botol plastik bekas dapat dapat dijadikan berbagai produk seperti lampu hias.

Ketercapaian tujuan pengabdian ditunjukkan pada antusias dan kemauan peserta pengabdian dalam mendengarkan materi pengabdian serta kegiatan pembuatan kerajinan berbasis pengelolaan sampah secara 3R. Antusias peserta pada sesi pemaparan materi adalah tanya jawab dari peserta kepada pemateri sedangkan antusias peserta pada pembuatan kerajinan adalah kemampuan peserta mengikuti pembuatan kerajinan yang dicontohkan/diperagakan oleh tutor.
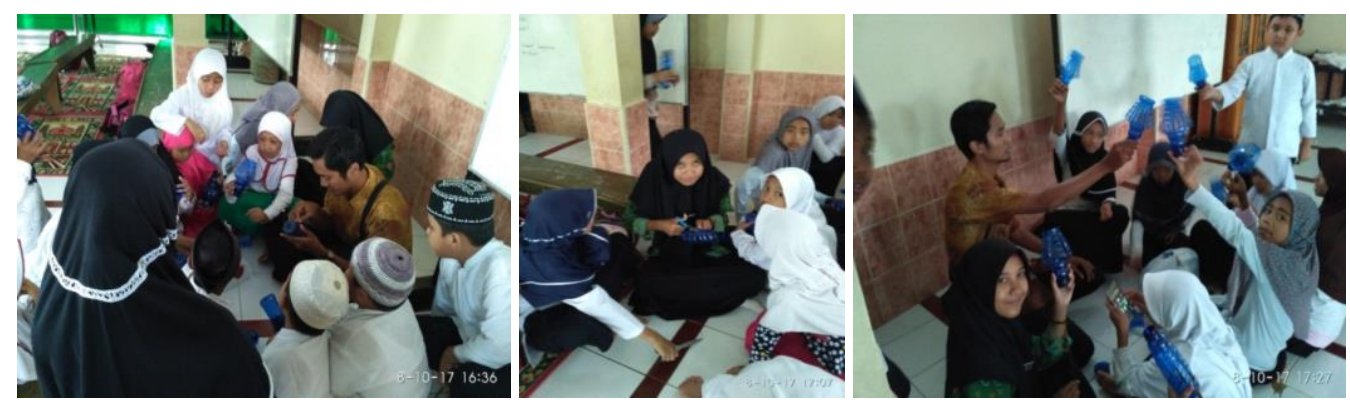

Gambar 4. Kegiatan Pelatihan dan Produk yang Dihasilkan

Ketercapaian target materi yang telah direncanakan dapat dikatakan sangat baik, dimana semua materi pengabdian dapat disampaikan secara keseluruhan. Materi yang telah disampaikan adalah jenis sampah, sumber sampah, dampak yang ditimbulkan akibat sampah pada media lingkungan serta pengelolaan sampah dan 3R (reduce, reuse, recycle) serta pembuatan kerajinan berbasis sampah botol plastic bekas menjadi lampu hias dan sapu.

Kemampuan peserta dalam penguasaan materidapat dikatakan baik. Hal ini didukung penggunaan metode ceramah dan demonstrasi/peragaan untuk meningkatkan kemampuan peserta pelatihan dalam menyerap materi yang disampaikan oleh nara sumber.

Secara keseluruhan kegiatan pengabdian pembuatan kerajinan berbasis sampah plastik sebagai implementasi pengendalian sampah 3R (reduce, reuse dan recycle) di TPQ Fatimatuzzahra Kota Bengkulu dinilai berhasil. Keberhasilan ini selain diukur dari keempat komponen diatas, juga dilihat dari kepuasan peserta setelah mengikuti kegiatan pelatihan. Manfaat yang diperoleh para peserta pelatihan adalah memahami pengelolaan sampah secara 3R dan membuat kerajinan dari sampah sehingga turut serta dalam menjaga kelestarian lingkungan disekitarnya.

\section{KESIMPULAN DAN SARAN}

\section{Kesimpulan}

Berdasarkan uraian yang telah disampaikan dalam pembahasan, dapat disimpulkan sebagai berikut:

a. Pengabdian pembuatan kerajinan berbasis sampah plastik sebagai implementasi pengendalian sampah 3R (reduce, reuse dan recycle) dapat meningkatkan pengetahuan para siswa tentang pentingnya menjaga lingkungan dan meningkatkan kreatifitas siswa dalam pembuatan kerajinan yang nantinya dapat bernilai ekonomi.

b. Metode ceramah dan demonstrasi/peragaan dalam pengabdian pembuatan kerajinan berbasis sampah plastik sebagai implementasi pengendalian sampah 3R (reduce, reuse dan recycle) dinilai cukup efektif untuk menyampaikan tujuan pengabdian. 


\section{Saran}

Kegiatan pengabdian ini diharapkan kedepan dapat sampai membuka akses produksi masyarakat pada pasar lokal (aneka kreasi daur ulang) dan dapat dilanjutkan pada tahuntahun berikutnya di lokasi lain untuk menunjang kelestarian lingkungan, disamping dapat meningkatkan kreatifitas peserta pengabdian.

\section{DAFTAR PUSTAKA}

Alex, S, 2000, Sukses Mengolah Sampah Organik Menjadi Pupuk Organik, 41-46.

Amri, C, dan Widiyantoro W, 2016, Pendampingan Pembelajaran Memilah Dan Menempatkan Sampah Pada Tempatnya Sejak Usia Dini, International Journal of Community Service Learning, 1:121-126.

Apryanti, C dan Dirgahayani P, 2012, Identifikasi Faktor Utama yang Berpengaruh pada Partisipasi Masyarakat dalam Pengelolaan Sampah di Kecamatan Coblong Kota Bandung, Jurnal Perencanaan Wilayah dan Kota: Bandung.

Dirgantar, B, 2013, Pengetahuan Mendaur Ulang Sampah Rumah Tangga dan Niat Mendaur Ulang Sampah. Studi Manajemn dan Organisasi, 10(1):2.

Marliani, M, 2014, Pemanfaatan Limbah Rumah Tangga (Sampah Anorganik) Sebagai Bentuk Implementasi Dari Pendidikan Lingkungan Hidup, Formatif. 4(2):124132.

Peraturan Daerah Nomor 02 Tahun 2011 Tentang Pengelolaan Sampah.

Peraturan Menteri Negara Ligkungan Hidup Nomor 13 Tahun 2012 Tentang Pedoman Pelaksanaan Reduce, Reuse dan Recycle Melalui Bank Sampah

Putra, H.P dan Yuriandala Y, 2010, Studi Pemanfaatan Sampah Plastik Menjadi Produk dan Jasa Kreatif, Jurnal Sains dan Teknologi Lingkungan, 2(1).

Syarofah, U, 2013, Kerajinan Seni: Cara Membuat Kerajian Tangan Lampu Hias Kamar Dari Botol Plastik Bekas, http://zhahab.blogspot.co.id/2013/12/karya-seni-caramembuat-kerajinan.html.

Tchobanoglous, T.G, dan S.A. Vigil, 1990, Integrated Solid Waste Mangement Engineering Principles and Mangement Issues, 5-8. 